\title{
A DIALOGIA BAKHTINIANA ENTRE AS ENUNCIAÇÕES JORNALÍSTICAS BRASILEIRAS DE 2020 E AS ENUNCIAÇÕES ARTÍSTICAS DE CHICO BUARQUE DA DÉCADA DE 70
}

\author{
THE BAKHTINIAN DIALOGY BETWEEN THE BRAZILIAN JOURNALISTIC \\ STATEMENTS OF 2020 AND THE ARTISTIC STATEMENTS OF CHICO BUARQUE \\ OF THE 70'S
}

\section{EL DIALOGÍA BAKTINIANA ENTRE LOS DECLARACIONES PERIODISTAS \\ BRASILEÑAS DE 2020 Y LAS DECLARACIONES ARTÍSTICAS DE CHICO \\ BUARQUE DE LOS 70}

\section{Enrico de Castro Carvalho Silva ${ }^{1}$}

Mestrando em Linguística Aplicada pela Universidade de Taubaté - Unitau

*Correspondência: UNITAU - Pró-reitoria de Pesquisa e Pós-graduação - Secretaria do Mestrado em Linguística Aplicada. Rua Visconde do Rio Branco, 210 - Centro Taubaté - SP CEP: 12020-040 - Tel.: (12) 3624-1657. e-mail enrico.carvalho2013@gmail.com.

Artigo recebido em 13/08/2020 aprovado em 03/11/2020 publicado em 19/03/2021.

\section{RESUMO}

O tema deste estudo é a relação dialógica dos enunciados concretos: Acabou pra você (2020), crônica escrita por Renato Terra, e Apesar de você (1970), composição de Chico Buarque de Holanda. A motivação desta abordagem se deve à possibilidade de ressignificação das práticas de leitura frente à demanda da sociedade contemporânea brasileira de formar um leitor crítico. O objetivo deste estudo foi verificar as relações dialógicas entre o enunciado concreto crônica, corrente na imprensa brasileira contemporânea, e a retomada histórica estabelecida por ele da enunciação de Chico Buarque da década de 70. O aporte teórico se refere às concepções sobre enunciação e dialogia de Bakhtin e O Círculo e à perspectiva historiográfica do Brasil construída por Schwarcz e Starling (2018). O procedimento metodológico de pesquisa é qualitativo interpretativo, do tipo documental. Os resultados deste estudo evidenciaram que a conclusibilidade de Apesar de você abriu possibilidade para a construção responsiva de Acabou pra você, evidenciando uma dialogia estruturada na retomada histórica. Conclui-se que a exposição da dialogia entre os enunciados possibilita uma compreensão mais completa dos processos de significação.

Palavras-chave: Dialogia; Enunciação; Significação.

\section{ABSTRACT}

The theme of this study is the dialogical relation between concrete statements: Acabou pra você (2020), chronicle written by Renato Terra, and Apesar de você (1970), composition by Chico Buarque de Holanda. The motivation for this approach is the possibility of reframing reading practices in face of the demand of contemporary Brazilian society to educate a critical reader. The goal of this study was to verify the dialogical relations between the concrete statement chronicle current in the contemporary Brazilian press, and the historical recapture of the statement by Chico Buarque in the 70s. The theoretical basis refers to the conceptions about enunciation and dialogy by Bakhtin and The Circle, and the historiographical perspective of Brazil by Schwarcz and Starling (2018). The methodological research procedure is qualitative interpretive, documentary type. The results of this study showed that the conclusibility of Apesar de você opened the possibility for a responsive construction of Acabou pra você, showing a dialogism based on historical resumption. It is concluded that the exposure of the dialog between the statements allows a more complete understanding of the meaning processes.

Keywords: Dialogy; Enunciation; Meaning. 


\section{RESUMEN}

El tema de este estudio es la relación dialógica de enunciados concretos: Acabou pra você (2020), crónica escrita por Renato Terra, y Apesar de você (1970), composición de Chico Buarque de Holanda. La motivación de este enfoque se debe a la posibilidad de replantear las prácticas lectoras en vista de la demanda de la sociedad brasileña contemporánea de formar un lector crítico. El objetivo de este estudio fue verificar las relaciones dialógicas entre el enunciado concreto, actual en la prensa brasileña contemporánea, y la reanudación histórica que estableció del enunciado de Chico Buarque en los años 70. El aporte teórico se refiere a las concepciones sobre enunciación y diálogo Bakhtin y El Círculo y la perspectiva historiográfica de Brasil construida por Schwarcz y Starling (2018). El procedimiento de investigación metodológica es interpretativo cualitativo, de tipo documental. Los resultados de este estudio mostraron que la contundencia de Apesar de você abrió la posibilidad para la construcción receptiva de Acabou pra você, mostrando un diálogo estructurado en la reanudación histórica. Se concluye que la exposición del diálogo entre los enunciados permite una comprensión más completa de los procesos de significado.

Descriptores: Dialogía; Enunciación; Significado

\section{INTRODUÇÃO}

A perspectiva dialógica de linguagem concebida por Bakhtin e seu Círculo é processual e não fundada na definição de modelos estanques. Nesse sentido a dinamicidade teórica funciona como elemento de fecundidade que possibilita uma diversidade infinita de aplicabilidade; mas ao mesmo tempo exige um cuidado metodológico quando à apreensão do objeto.

O objetivo deste estudo foi verificar as relações dialógicas entre o enunciado concreto crônica, corrente na imprensa brasileira contemporânea, e a retomada histórica estabelecida por ele da enunciação de Chico Buarque da década de 70.

Diante da complexidade dos processos de significação de enunciados, uma vez que Bakhtin (2018) os concebe como elos de uma cadeia discursiva infinita, a compreensão das relações dialógicas possibilita uma compreensão semiótica mais apurada referente à leitura.

Inicialmente, serão apresentados conceitos fundamentais referentes à concepção bakhtiniana de linguagem desenvolvidos por Volóchinov (2018), Bakhtin (2011) e seus intérpretes: Brait (2018), Melo (2018), Fiorin (2018) e Miotello (2018) para que se possa articular a visão de dialogia entre os enunciados concretos selecionados. $\mathrm{Na}$ sequência será desenvolvida uma breve perspectiva historiográfica de Starling e Schwarcz (2015) como intuito de compreender as condições de emergência do enunciado de Chico Buarque.

\section{MATERIAIS E MÉTODOS}

O procedimento metodológico de pesquisa é qualitativo interpretativo, do tipo documental. Segundo Godoy (1995, p. 21, 22) os documentos configuram "uma fonte natural de informações à medida que, por terem origem num determinado contexto histórico, econômico e social, retratam e fornecem dados sobre esse mesmo contexto". Assim, o corpus deste estudo será retratado linguisticamente.

As condições de emergência do enunciado de Renato Terra, por referirem-se à atualidade, são desenhadas por meio de análise das duas enunciações correntes na imprensa: Bolsonaro afirma que torturador Brilhante Ustra é um "herói nacional" publicada pela Revista Veja em 2019 e Covid, 11.519 mortos: Sob Bolsonaro, Presidência vira serviço não essencial pelo colunista do UOL, Leonardo Sakamoto em 2020.

Postos alguns elementos indispensáveis da perspectiva bakhtiniana e a contextualização sócio histórica dos enunciados, será feita a análise da dialogia e seu impacto no processo de leitura e compreensão. 


\section{INTERAÇÃO DISCURSIVA}

O ponto de partida do desenvolvimento dos conceitos basilares da Análise Dialógica do discurso pertinentes a este trabalho é a perspectiva apresentada por Volóchinov (2018) em Marxismo e filosofia da linguagem e por Bakhtin (2011) em Estética da Criação Verbal sobre a constituição do sujeito por meio da linguagem, enunciado concreto e gênero do discurso.

Inicialmente, é essencial destacar as críticas que Volóchinov (2018) tece às concepções de expressão e consciência atreladas aos pensamentos filosófico-linguísticos

Racionalismo/Neoclassicismo

Romantismo/Subjetivismo Individualista.

O Romantismo surge de modo responsivo à extrema racionalização neoclássica e marca o aparecimento dos primeiros filólogos trazendo reflexões linguísticas sobre fundamentos do pensamento por meio da língua materna, tido como forma de manifestação da consciência. O principal questionamento epistemológico é a visão de enunciação monológica como expressão de uma consciência individual, deslocada da dinâmica social.

O processo de enunciação é determinado pela situação social comunicativa na qual interlocutores estabelecem interações. Nesse processo há possibilidade, no processo de enunciação, de se estabelecer uma substituição de um interlocutor real por um representante médio do grupo social, na medida em que não é possível a existência de um locutor abstrato.

Nota-se então, que a enunciação é diretamente influenciada pelo meio social, ou seja, o contexto social e histórico determina a criação ideológica do grupo social. Sobre o viés cultural é destacado que:

Quanto mais culto for o indivíduo, tanto mais o seu auditório se aproximará do auditório médio da criação ideológica, mas, em todo caso, o interlocutor ideal não é capaz de ultrapassar os limites de uma determinada época (VOLÓCHINOV, 2018, p. 205).

Assim, uma vez que a palavra é tida como um produto de interação entre locutor e ouvinte e estes estão inseridos um contexto socio-histórico culturalmente delimitado, são explicitadas as duas faces da palavra: a procedência de alguém e direcionamento para alguém. Os sujeitos que interagem, ao mesmo tempo, integram e são representantes da coletividade e quanto maior repertório cultural o indivíduo possuir, mais especificidades ele será capaz de atribuir ao seu auditório, no contexto de criação ideológica.

O locutor está fortemente vinculado situação social e ao meio social durante o processo de enunciação, a própria estrutura da enunciação é determinada por forças sociais e submetem o locutor. Há um distanciamento da perspectiva bakhtiniana do subjetivismo romântico baseado na consciência individual; na medida em que considera elementos socioculturais como influentes no processo enunciativo, nesse sentido afirma-se que:

[...] a diferenciação ideológica e o aumento da consciência são diretamente proporcionais à firmeza e à convicção da orientação social. Quanto mais unida, organizada e diferenciada for a coletividade na qual se orienta um indivíduo, tanto mais diversificado e complexo será seu mundo interior (VOLÓCHINOV, 2018, p. 208).

Volóchinov (2018) aborda o conceito de atividade mental com três subdivisões: atividade mental no eu, atividade mental do nós e atividade mental para si. Quanto ao "eu" a atividade mental tende ao isolamento e perde a representação verbal prejudicando a clareza, pois não consegue se fixar socialmente; no que diz respeito "ao nós" a atividade mental é orientada pela coletividade interior; já o "para si” adiciona à atividade mental a ideia de status social que se realiza exclusivamente a serviço da coletividade. As atividades mentais "do nós" e "para si" configuram duas perspectivas de coletivo, contudo 
esta última prevê "um direito enquanto indivíduo isolado" e é, principalmente, este conceito que norteará a estruturação da dinâmica entre concepção bahktiniana e a prática em sala de aula para análise de enunciados concretos, que será explicitada e desenvolvida mais adiante.

Prosseguindo, o autor dá continuidade às reflexões sobre consciência e menciona etapas de objetivação que caracterizam a consciência como uma força real com potencial de ação.

Enquanto a consciência permanece na cabeça daquele que pensa como um embrião verbal da expressão, ela é apenas uma parte muito pequena da existência, com um campo de ação reduzido. No entanto, quando ela passa todos os estágios da objetivação social e entra no campo da força da ciência, da arte, da moral, do direito, ela se torna uma verdadeira força, capaz até de exercer uma influência inversa nas bases econômicas da vida social. É claro, a força da consciência está na sua encarnação em determinadas organizações sócias e na sua fixação em expressões ideológicas estáveis (VOLÓCHINOV, 2018, p. 212).

Entretanto, assim como existe a possibilidade da consciência agir sobre a vida social, há também um processo que é denominado de ação reversiva no qual há bloqueio da atividade mental desencadeando uma expressão interior, em contrapartida à tendência de expressão exterior; este processo evidencia o poder do contexto sociocultural sobre a consciência, uma vez que o mundo interior assimila as possibilidades de nossa expressão.

A ideologia também tem espaço no desenvolvimento teórico da perspectiva bakhtiniana e será pormenorizada mais adiante neste trabalhado. Por hora, cumpre destacar que a Análise Dialógica do Discurso considera como sistemas ideológicos constituídos, a arte, a moral, a ética, o direito e assim entende que as palavras se fixam nos sistemas ideológicos.

Entretanto, os sistemas ideológicos constituídos só têm vida a partir da ideologia do cotidiano que permite a criação de ligações com o conteúdo total da inconsciência dos indivíduos, ou seja, pode ser considerada um fator de agrupamento social.

A ausência de vínculo social, o isolamento, a incapacidade de constituir uma expressão completa é denominada de atividade mental fortuita. Esta concepção figura como um reforço, por parte do autor, de que a ideologia do cotidiano é indispensável para estabelecer vínculos sociolinguísticos.

Em termos de enunciação os fatores sociológicos/ideológicos são considerados mais relevantes em detrimento dos biográficos/biológicos, nesse sentido, de modo enfático a concepção bakhtiniana de linguagem refuta a teoria de expressão subjacente ao subjetivismo. Os argumentos se firmam no fato do subjetivismo individualista não abordar a natureza social da enunciação, na tentativa de redução ao mundo interior do locutor. Há uma consideração por parte da teoria da existência de relação entre forma linguística e conteúdo ideológico, porém não considera a impossibilidade de reduzir este conteúdo ao psiquismo individual.

Volóchinov (2018) promove uma aproximação entre o subjetivismo individualista e o objetivismo abstrato, no sentido de ambos terem o mesmo ponto de partida: a enunciação monológica. Também faz críticas objetivas a dois teóricos Leo Spitzer e Otto Dietrich. É posto que os estudos spitzerianos sobre diálogo levam em conta condições sociais no interlocutor, contudo critica seu método por ser psicológico-descritivo e não apresentar conclusão coerentes em termos sociológicos. Quanto à visão dietrichana, a crítica se baseia no fato de ver a função central da linguagem como a comunicação e não a expressão, havendo assim uma redução à relação locutor-ouvinte, ademais ainda há utilização de premissas psicológicas do subjetivismo individualista.

Resta claro até aqui, que o autor não é convencido pelos argumentos que estruturam o 
subjetivismo individualista, ou os considera incompletos quando deixam de lado a influência da ideologia do cotidiano, elemento essencialmente social para explicar a língua.

A realidade efetiva da linguagem não é o sistema abstrato de formas linguísticas nem o enunciado monológico isolado, tampouco o ato psicofisiológico de sua realização, mas o tecimento social da interação discursiva que ocorre por meio de um ou de vários enunciados (VOLÓCHINOV, 2018, p. 218-219).

Neste ponto, no que diz respeito ao discurso tecido socialmente, Bakhtin (2011) desenvolve conceitos sobre gêneros discursivos que surgem diante da necessidade de atender as necessidades sociais comunicativas. Posta a fluidez dessas necessidades os gêneros discursivos também fluem sóciohistoricamente.

Os enunciados contemplam elementos estruturantes relacionados às condições e finalidades dos campos da atividade humana, quais sejam: conteúdo temático, estilo de linguagem e construção composicional. O autor aponta que "cada enunciado particular é individual, mas cada campo de utilização da língua elabora seus tipos relativamente estáveis de enunciados" e a este conjunto atribuiu a denominação de "gêneros do discurso".

Os gêneros do discurso expressam a multiformidade da atividade humana e como exemplo da heterogeneidade das diversas possibilidades orais e escritas, destacam-se as comunicações dialógicas do cotidiano, os relatos, as ordens, documentos oficiais, etc. Os diversos gêneros incluem-se de numa dinâmica de "heterogeneidade funcional" que confere certa dificuldade ao estudo, pois configuram um grande nível de abstração dos desenhos dos gêneros discursivos.

A perspectiva epistemológica linguística, até o momento apontado por Bakhtin em seu texto, não contempla uma abordagem voltada para a diversidade dos gêneros discursivos. Desde a Antiguidade o foco era a caracterização artística-literária e, portanto, os objetos de estudo eram os gêneros literários com a análise linguística negligenciada. O estudo dos gêneros retóricos contribuiu timidamente para uma perspectiva linguística enunciativa (sendo o enunciado compreendido aqui como conclusividade do pensamento).

Posteriormente, os gêneros discursivos do cotidiano, concebidos como transcrição de diálogos, foram abordados segundo as perspectivas linguísticas de Saussure, do Behaviorismo e de Vossler afastandose da visão do Círculo de Bakhtin. Saussure buscava compreender os elementos constitutivos da língua o que gerou uma certa abstração; os behavioristas trouxeram uma abordagem psicológica de condicionamento comportamental por meio de comandos e Vossler, por fim, constrói uma análise histórica que leva em conta primordialmente a individualidade estilística dos sujeitos. Todas essas teorias são monológicas pois desconsideram o contexto social em que a linguagem se constitui, em contrapartida a Bakhtin que vê o "eu" como sujeito e o "outro" como sociedade.

A dificuldade de caracterização da natureza geral do enunciado advém da heterogeneidade dos gêneros. Nesse sentido é proposta uma diferenciação entre gêneros discursivos primários, que são mais simples e ligados à comunicação discursiva imediata; e gêneros discursivos secundários, que são mais elaborados e ligam-se ao convívio cultural complexo.

Os gêneros secundários absorvem e transformam os gêneros primários e essa incorporação faz com que os enunciados percam o vínculo com a realidade concreta imediata. A compreensão da complexidade dos enunciados nesse contexto, depende do estudo bilateral dos gêneros primários e secundários, uma vez que eles se relacionam entre si.

O percurso histórico é responsável pelo processo de formação dos gêneros secundários que 
evidenciam a natureza do enunciado e a relação recíproca entre linguagem e ideologia. Os enunciados concretos tanto na forma escrita quanto oral estão presentes em todos os campos da atividade humana e configuram fatos linguísticos a serem pesquisados.

No contexto de estudo da natureza dos enunciados eles também são diferenciados em primários e secundários, adquirindo uma equivalência de terminologia metodológica com gêneros discursivos. De forma complementar, no contexto de investigação linguística, a natureza dos enunciados diversos se relaciona com os diversos gêneros do discurso. Essas abordagens privilegiam uma investigação do vínculo com o percurso histórico e as relações entre a língua e a vida, contudo neste ponto o autor apresenta uma diferenciação entre enunciados e gêneros discursivos.

O elo entre a língua e a vida é o enunciado concreto, reside nesse fato a importância do estudo desse elemento sob diversos enfoques linguísticos. Um dos enfoques proposto por Bakhtin é o estilístico. A esse respeito estilo é apresentado como elemento associado ao gênero discursivo e este, por sua vez, determina o nível de possibilidade da expressão subjetiva de cada indivíduo.

Cada atividade humana demanda um gênero discursivo específico e este, por sua vez, demanda estilos funcionais. Bakhtin (2011) ressalta que o estudo do estilo da linguagem deve manter o vínculo com os gêneros do discurso, o que não ocorria até o momento, gerando dificuldades quanto à uma organização classificatória. A classificação, segundo o autor, deveria considerar os campos de atividade do discurso.

A constante mudança das relações sociais ao longo da história é acompanhada pela mudança na linguagem - caracterizada pela dinâmica entre enunciado, estilo e gêneros discursivos. Dessa forma na medida em que os gêneros do discurso, tanto primários quanto secundários, compõem a literatura são os elementos determinarão o ritmo de evolução da linguagem literária. Sob essa perspectiva há um caminho de progressiva complexidade comunicativa composto por camadas extraliterárias, que são percorridos pela oralidade até a estruturação dos gêneros primários e secundários.

O estilo tem a potencialidade de modificar os gêneros discursivos a ele atrelados, portanto não podem ser estudados de forma separada. $\mathrm{O}$ estudo da língua contempla várias metodologias, é possível priorizar a gramática ou a estilística, contudo é preciso compreender que estas perspectivas se relacionam, porque as próprias escolhas dentre as opções gramaticais são recursos de estilo.

A compreensão da língua como fenômeno concreto depende da análise dos enunciados e dos gêneros do discurso sob o âmbito global que envolve gramática e estilística. Assim há superação da concepção monológica que é incapaz de conceber toda complexidade do discurso.

Quanto ao enunciado posto como unidade de comunicação discursiva o autor inicia sua análise pela perspectiva linguística do século XIX, em especial referente a Wilhem Humbolt, que considera a linguagem como componente estruturante do pensamento humano "independente da comunicação". Além disso destaca as correntes vosslerianas que priorizam a função expressiva, ou seja, o falante expõe sua individualidade ao mundo linguisticamente. A crítica de Bakhtin à essas teorias se pauta na desconsideração que elas fazem da importância da função comunicativa da linguagem, que prevê além do falante (eu) a sociedade (outro).

O enunciado deve ser visto sob uma duplicidade: o pensamento e seu produtor. A enunciação é elaborada não somente em função de um repertório historicamente construído, mas também levando em conta a reação comunicativa do outro. 
Um traço essencial (constitutivo) do enunciado é o seu direcionamento a alguém, o seu endereçamento. À diferença das unidades significativas da língua - palavras e orações -, que são impessoais, de ninguém e a ninguém estão endereçadas, o enunciado tem autor (e, respectivamente, expressão do que já falamos) e destinatário (BAKHTIN, 2011, p. 301).

O destinatário de um enunciado pode ser concebido como coletividade ou como indivíduo e cada gênero discursivo, atrelado a diferentes campos de atuação humana, é determinado por esse destinatário. A construção do estilo também leva em conta a caracterização do destinatário e essa, do mesmo modo, influencia o gênero ao qual o enunciado estará atrelado.

De forma conclusiva Bakhtin retoma a literatura caracterizada pela multiplicidade discursiva, na medida em que incorpora diversos gêneros discursivos secundários que, por sua vez, são formados por gêneros primários e esses por enunciados. Diante dessa perspectiva o enunciado é diferenciado das palavras e orações sob o aspecto de não configurar uma unidade linguística simples e vazia de destinatário, mas como um conjunto de escolhas dentre as possibilidades de uma língua e, portanto, passível de ser concebido estilisticamente.

\section{ENUNCIAÇÃO}

Brait e Melo (2018) concebem a abordagem de enunciação bakhtiniana sob o âmbito da dinamicidade. Independente da extensão do enunciado ele prevê ao mesmo tempo um começo absoluto - expressão de uma variedade de enunciados proferidos anteriormente por outros sujeitos - e um fim absoluto - enunciados resposta dentro de um processo comunicativo.

Os termos enunciado, enunciado concreto e enunciação têm acepções epistemológicas diversas dentro da linguística e elas serão diferenciadas da visão bakhtiniana. É reforçado que Bakhtin só confere sentido aos termos de forma relacional a diversos outros conceitos. Dessa forma, a polissemia dos termos é formada por uma diversidade de teorias coerentes entre si e a exposição pelas autoras de algumas delas tem como objetivo localizar os pressupostos semânticos utilizados.

É ressaltado que existem diversas concepções de enunciado que abarcam a possibilidade de análise fora do seu contexto de comunicação: frase, sequência frasal, organização sintática sequencial de palavras. Em contrapartida, há também concepções de enunciados como unidades comunicativas essencialmente contextualizadas, nas quais o significado está vinculado às situações de produção.

A pragmática linguística é referenciada como momento teórico em que a extralinguagem (inferência e contexto) é vinculada ao enunciado no processo de significação. Nesse sentido, é apontada pelas autoras a visão de Oswald Ducrot, que apresenta uma diferenciação entre frase, enunciado e enunciação. Há uma influência bakhtiniana em Ducrot, principalmente quanto ao conceito de polifonia (várias vozes num enunciado), contudo ainda há uma restrição aos elementos textuais, fato que demonstra uma incompletude com relação à perspectiva do Círculo de Bakhtin, que considera o exterior social como integrante ao enunciado.

Posteriormente, as autoras supracitadas ressaltam as reflexões do Círculo de Bakhtin, primeiramente sobre a influência da história, cultura e sociedade na língua, e depois sobre a perspectiva enunciado-discursiva da linguagem. Essa concepção contribui para a construção dos conceitos de: enunciado/enunciação, signo ideológico, palavra, comunicação, interação, gêneros discursivos, texto, tema e significação, discurso, discurso verbal, polifonia, dialogismo, ato/atividade/evento.

Novamente é feito um destaque para o fato de que o conceito de enunciado/enunciação é composto 
pelo conjunto das obras do Círculo, antes de ser dado destaque à análise de Discurso na vida e discurso na arte - sobre poética sociológica por Voloshinov em 1926. A obra destaca a relação entre enunciado e discurso verbal, enunciado concreto e palavra, enunciação e evento; sob essa perspectiva é feita uma breve caracterização de enunciado poético como ato comunicativo de peculiaridades estéticas.

Brait e Melo (2018) ressaltam a possibilidade de fusão conceitual, nas obras de Bakhtin, entre enunciado concreto e palavra, texto, discurso. Contudo, o conceito de enunciação na obra Marxismo e filosofia da linguagem com tradução por Michel Lahud e Yara Frateschi, aparece como:

[...] na fronteira entre a vida e o aspecto verbal do enunciado; ela, por assim dizer, bombeia energia de uma situação da vida para o discurso verbal, ela dá a qualquer coisa linguisticamente estável seu momento histórico vivo, seu caráter único (VOLOSHIVOV in BRAIT e MELO, 2018, p. $67,68)$.

Diante dessa perspectiva, cumpre destacar que a ideia de enunciação constituída por elementos interativos sociais, históricos e culturais é difundida e assim "liga-se a enunciações anteriores e a enunciações posteriores, produzindo e fazendo circular discursos" (BRAIT e MELO, 2018, p. 68). Dessa forma fica evidente que os conceitos linguísticos bakhtinianos são amplos, indissociáveis e articuláveis, em especial enunciação e dialogia.

\section{RELAÇÕES DIALÓGICAS}

Bakhtin (2002) preconiza que a utilização da linguagem está atrelada ao sujeito localizado no tempo de espaço, que considera sempre a existência do outro social para estabelecer sua comunicação. Nesse sentido, inicialmente faz-se necessário explicitar dois vieses quanto à dialogia bakhtiniana: a consideração imediata do discurso "do outro" na elaboração do processo enunciativo e a retomada dos discursos iniciados num passado histórico e que constituem um repertório sociolinguístico.

$\mathrm{O}$ artista-prosador edifica este multidiscurso social em volta do objeto até a conclusão da imagem, impregnada pela plenitude das ressonâncias dialógicas, artisticamente calculadas em todas as vozes, e entonações essenciais desse plurilinguismo. Mas, como dissemos, qualquer discurso da prosa extra artística - de costumes, retórica, da ciência - não pode deixar de se orientar para o "já dito", para o "conhecido", para a "opinião pública", etc. A orientação dialógica é naturalmente um fenômeno próprio a todo o discurso. Trata-se da orientação natural de qualquer discurso vivo. Em todos os seus caminhos até o objeto, em todas as direções, o discurso se encontra com o discurso de outrem e não pode deixar de participar, com ele, de uma interação viva e tensa. Apenas o Adão mítico que chegou com a primeira palavra num mundo virgem, ainda não desacreditado, somente este Adão podia realmente evitar por completo esta mútua-orientação dialógica do discurso alheio para o objeto. Para o discurso humano, concreto e histórico, isso não é possível: só em certa medida e convencionalmente é que pode dela se afastar (BAKHTIN, 2002, p.88).

Cabe ressaltar que o discurso literário para a Análise Dialógica do Discurso é concebido como um exemplar sintético multidiscursivo, contempla diversas camadas dos discursos que emergem na sociedade. Portanto é possível compreender o "artistaprosador" como um locutor em sentido amplo.

Segundo Fiorin (2018) os termos relacionados ao intertexto e interdiscurso não figuram de modo literal da obra de Bakhtin. O termo "intertextual" aparece uma vez ao longo de toda produção teórica e ainda oriundo de um equívoco de tradução. Contudo, levando em conta importância do desenvolvimento conceitual do termo o autor busca verificar se a teorização de Bakhtin não se desenvolve a partir de terminologias próprias.

O termo "intertextualidade" foi um dos primeiros a estabelecer relação com a teoria bakhtiniana, segundo a tradução de Júlia Kristeva. Fiorin ressalta que a autora inicia suas análises das teorias de Bakhtin em 1967 partindo das obras 
Problemas da poética de Dostoiéviski e A obra de François Rabelais.

Considerando o discurso literário como um conjunto de camadas discursivas e um diálogo entre vários textos e citações, a concepção bakhtiniana apresentada inicialmente sobre texto aborda conclusibilidade e responsividade. Desse modo, o texto surge em resposta a discursos anteriores e ao mesmo tempo possibilita novas respostas por textos posteriores.

$\mathrm{O}$ autor apresenta uma redefinição da perspectiva tradicional sobre texto com base na perspectiva de Roland Barthes, que consiste numa divisão linguística na qual o escrito figura na superficialidade e é imediatamente perceptível e estável, enquanto a fluidez da memória e historicidade das instituições e os valores sociais figuram da essência. Posteriormente Barthes redefine novamente texto diante de um ponto de vista divergente da metafísica anterior e o considera como uma organização linguística por meio de palavras que carregam vários enunciados.

Saussure também por meio de sua perspectiva sobre compreensão textual que contrapõe Barthes. A visão saussureana prevê que a compreensão textual ocorre no âmbito da abstração posta pela língua, já em Barthes o entendimento de um texto se realiza na comunicação entre o indivíduo, o outro e o contexto social.

São contextualizados alguns termos usados por Barthes e Kristeva utilizados para estruturar a argumentação de que o sujeito se constitui e a língua de reconstrói por meio do texto. Assim a significância é vista como desconstrução do sujeito por meio do embate com o texto; fenotexto como fenômeno verbal constituinte do enunciado e genotexto como lugar de materialização do fenotexto, onde o sujeito da enunciação se constitui no processo de significação.
Fiorin (2018) chama atenção para o fato de que a terminologia usada por Bakhtin para referir-se à teorização do processo tradicionalmente denominado como intertextualidade é "dialogismo". Além disso, entende que a ideia de discurso é indissociável da relação intersubjetiva de locutores. Assim o diálogo não pode ser considerado de modo fragmentado em interação pessoal entre interlocutores e interação de discursos, há correlação entre os elementos.

Sob essa ótica, as relações dialógicas contemplam toda a forma de enunciação, por isso não se deve reduzir os estudos a uma teorização sobre conversações. $\mathrm{O}$ discurso representa o autor que constrói seu pensamento humano com base no dialogismo. O pensamento, por sua vez, se realiza por meio da relação interdependente entre texto e contexto.

É posto que Bakhtin considera dois aspectos essenciais do dialogismo: ser esse um elemento basilar da linguagem, bem como um modo de composição discursiva. Ademais a realidade é mediada por meio da linguagem e na medida em que o discurso se constitui na relação dialógica com o outro, a percepção do que é real é influenciada pela utilização que o outro faz da linguagem. Assim, ele não refuta a importância do estudo da língua como código, contudo ressalta que esse estudo isolado dos processos translinguísticos é insuficiente para explicar a linguagem.

É feita uma diferenciação entre enunciado como elo, ou unidade comunicativa e oração como unidade da língua, pois aquele é fruto de um processo único de significação subjetiva e dialógica. Os enunciados suscitam respostas, deferente das palavras e orações. Esta conclusibilidade se deve a uma autoria adquirida e a um destinatário determinado. Ainda, mediante a isso há uma diferença entre sentido e significação; essa diz respeito à relação entre palavras e aquele ao dialogismo enunciativo que é carregado da tensão constante entre posições sociais. 
No que diz respeito a quem se dirige o enunciado, Fiorin (2018) afirma que o interlocutor não está diluído numa coletividade, ele constrói sua individualidade na interação das vozes sociais. Portanto, o dialogismo é estruturado tanto no âmbito individual quanto no social, uma vez que o locutor do enunciado busca alcançar o interlocutor imediato através de uma visão de mundo socialmente construída. É possível, desse modo afirmar que todo interlocutor tem sua identidade constituída por um superdestinatário.

O desenvolvimento teórico do termo "texto" é retomado sob a perspectivada de Bakhtin na obra $O$ problema do texto como opção do autor supracitado para delimitar a multiplicidade de significados terminológicos. Neste ponto o texto se difere do enunciado sob o ponto de vista da potencialidade. $\mathrm{O}$ texto é só assim denominado enquanto fruto de uma relação imediata entre signos linguísticos; quando o texto passa a ser preenchido pela dialogia ele se torna enunciado.

O termo comunicação verbal também é diferenciado do termo discurso. O discurso é uma abstração constituída por enunciados ilimitados que irão determinar uma identidade social, enquanto a comunicação verbal é uma dialogia mediada por enunciados.

Interdiscurso e intertexto começam a ser delineados por Fiorin (2018) como elementos relacionais. A interdiscursividade é pressuposto de existência da intertextualidade, mas a relação contrária é equivocada. Diante do desenvolvimento anterior dos conceitos de texto e discurso, é possível notar que o intertexto demanda uma materialidade linguística, já o interdiscurso há relação dialógica entre enunciados em sua amplitude ilimitada.

De forma sintética, pode-se dizer que o autor faz uma leitura bakhtiniana de intertextualidade como encontro de duas materialidades linguísticas, figurando como uma especificidade de interdiscursividade que é um diálogo entre enunciados. Dessa forma, fica claro que o discurso para Bakhtin é linguístico e histórico, sendo a história discursiva concebida como um processo de significação de enunciados interdependentes que concretizam a relação entre sujeito e contexto social.

\section{IDEOLOGIA}

Para o desenvolvimento das concepções sobre ideologia, cumpre destacar Volóchinov (2018) em Marxismo e filosofia da linguagem quanto as relações entre signo, ideologia e relações sociais. A ideologia concebe um universo de refração da realidade através de um processo de significação dos signos construída socialmente.

Um signo só pode surgir em um território interindividual, que não remete à natureza no sentido no sentido literal dessa palavra. $\mathrm{O}$ signo tampouco surge entre dois Homo sapiens. É necessário que esses dois indivíduos sejam socialmente organizados, ou seja, componham uma coletividade - apenas nesse caso um meio sígnico pode formar-se entre eles. A consciência individual não só é incapaz de explicar algo nesse caso, mas ao contrário, ela mesma precisa de uma explicação que parta do meio social e ideológico (VOLOSHIVOV, 2018, p. 96, 97).

Miotello (2018) aponta que O Círculo de Bakhtin aborda o conceito de ideologia de modo diferenciado, aprofundando conceitos que não haviam sido contemplados pelo marxismo. $\mathrm{O}$ desenvolvimento do conceito encontra-se diluído em várias obras do Círculo, contudo há uma concentração teórica em Marxismo e Filosofia da Linguagem e Problemas da Poética de Dostoievski.

A crítica quanto à abordagem marxista sobre ideologia refere-se à sua contextualização, que estabelece majoritariamente uma dinâmica entre as relações socioeconômicas e superestruturas ideológicas. A crítica se estende às Ciências Humanas que, de modo geral, abordavam ideologia de duas formas insuficientes: subjetiva/interiorizada e 
idealistas/psicologizada. A incompletude dessas abordagens deve-se ao fato de não considerarem a ideologia como um elemento vivo que dialoga constantemente com o exterior do indivíduo.

A concepção bakhtiniana de ideologia parte do pressuposto marxista, que considera a imposição de uma classe social dominante de uma deturpação da percepção da realidade. Contudo, há um avanço no sentido da construção conceitual por meio do acréscimo das perspectivas de ideologia do cotidiano e ideologia oficial. A ideologia oficial busca a imposição de uma visão de mundo única, enquanto a ideologia do cotidiano advém das relações sócias do dia-a-dia.

Os dois tipos de ideologia se contrapõem constantemente numa dinâmica de estabilidade e instabilidade. Assim, afirmações dos indivíduos são postas por um contexto ideológico heterogêneo, portanto a compreensão dos discursos depende de uma oposição dialética.

A partir de uma apresentação literal de um conceito de ideologia proposto por Voloshinov, o autor afasta a definições de "falsa consciência" e "expressão de uma ideia" e se aproxima da ideia de discurso responsivo à realidade social. A compreensão do Círculo sobre ideologia é construída por meio de um método marxista que parte de reflexões sobre o processo de significação dos objetos materiais. Nesse ponto há exposição de um elo entre a concepção sobre ideologia e sobre signo. As relações sociais organizam o processo de significação dos objetos para além de sua materialidade.

A linguagem compreendida como fenômeno de interação entre indivíduos por meio da palavra consolida a ideia de que o signo é indissociável da ideologia. Um sistema de valores delimitado histórica e socialmente constitui um processo ideológico de atribuição de significados aos signos e esses, de forma retributiva, integram um fenômeno ideológico.
As comunicações casuais são permeadas por diversas ideologias do cotidiano atreladas a diferentes grupos sociais. Desse modo, por meio de encontros não planejados os indivíduos estabelecem uma interação entre diferentes processos de significação e dessa interação verbal intersubjetiva constitui-se a consciência.

Miotello (2005, p.171) apresenta a possibilidade de "caracterizar a ideologia, da perspectiva bakhtiniana, como a expressão, a organização e a regulação das relações históricomateriais dos homens". Diante desse ponto de vista, o universo da significação é posto em destaque como expressão da tensão entre ideologia do cotidiano e ideologia oficial. Assim, uma vez que os discursos são o estopim do processo de significação, não é possível afirmar que existe neutralidade, pois há sempre algum vínculo com um sistema ideológico, que por sua vez estabelece vínculo com um grupo social.

Os signos são polifônicos pois passam por um processo de significação atrelado ao momento histórico, ao grupo social e à ideologia, ou seja, a polissemia das palavras se deve ao potencial que elas têm de carregar diferentes contextos valorativos e vozes discursivas.

Por mais que a ideologia do cotidiano se instaure nas relações do dia-a-dia, existe em certos momentos uma estabilidade nos encontros dos indivíduos; os agrupamentos sociais são organizados pela partilha de valores. Esses agrupamentos têm sua organização, em certa medida, influenciada pelas instituições ideológicas. Assim, a ideologia do cotidiano é afetada, mas também afeta a ideologia oficial, obrigando que a classe dominante imponha seus valores às classes dominadas por meio de um processo de significação monovalente.

O processo de significação dos sistemas ideológicos oficiais ocorre em dois âmbitos: 
(a) estrato inferior da ideologia do cotidiano onde se dão os encontros fortuitos e por tempo limitado, e as atividades mentais e a consciência se apresentam sem a modelagem ideológica clara; (b) estrato superior da ideologia do cotidiano - onde essa multiplicidade de fios ideológicos, constituídos na multiplicidade de atividades e relações sociais, encontra sua primeira tessitura, e onde, portanto, repercutem as rapidamente as mudanças da infra-estrutura socioeconômica (MIOTELLO, 2018, p. 174).

Assim, a possibilidade de mudança da ideologia dominante está vinculada a um percurso de transformação da ideologia do cotidiano. Numa primeira fase os encontros fortuitos dos indivíduos proporcionam um diálogo que atribuirá sentido aos signos, numa segunda fase os indivíduos encontram-se nos agrupamentos organizados pelos poderes políticos institucionalizados (religioso, jurídico, moral, etc). É nessa segunda fase, devido à proximidade gerada pela organização do agrupamento, que a ideologia do cotidiano modificará a ideologia oficial.

Diante da necessidade perpétua dos indivíduos se relacionarem e da progressão de complexidade dessas relações até o nível de institucionalização, a ideologia do cotidiano promove uma metamorfose de valores e significados. Nesse sentido, o autor lança mão de exemplo do casamento, afirmando que a significação imposta pela ideologia oficial a respeito desse acontecimento social era restrita à união de indivíduos de gêneros diferentes. Ao longo do tempo as relações sociais foram reconstruindo o sistema de significados ligados ao casamento e reestabelecendo uma modificação da ideologia do cotidiano, que progressivamente acarretou mudanças na ideologia oficial, concebendo a união entre pessoas de mesmo gênero.

A argumentação do autor é concluída com a afirmação de que o indivíduo, diante da perspectiva de Bakhtin e do Círculo, é reflexo da dialogia entre o indivíduo e o mundo e entre o eu e o outro social. Esses diálogos são reflexos de um complexo processo ideológico-relacional entre signo, realidade material e comunicação concreta. O indivíduo é construído pelo diálogo responsivo com meio social no qual está inserido e sua relação com o meio irá determinar a forma que ele irá lidar com o mundo material. Essa forma de atribuição de significados, de construção de sistemas simbólicos caracterizam os sistemas ideológicos.

\section{CONDIÇÕES DE EMERGÊNCIA DA ENUNCIAÇÃO DE CHICO BUARQUE}

Considerando o que foi desenvolvido sobre a os conceitos de enunciação e dialogismo sob a ótica bakhtiniana, antes da apresentação da análise documental, é indispensável localizar sóciohistoricamente Chico Buarque de Holanda que figura como enunciador.

Dada cronologia da emergência enunciativa de Apesar de você, cabe a contextualização histórica do período, referente à duração de 21 anos da Ditadura Militar instaurada no Brasil em 1964. Posteriormente

à instauração foram publicados quatro Atos Institucionais que restringiram diversos direitos $\mathrm{e}$ garantias fundamentas do povo brasileiro. Schwarcz e Starling (2018) traçam um panorama do processo de recrudescimento da repressão promovida pelo governo, especialmente levando em conta a censura institucionalizada pelo Estado naquele período:

Em 14 de dezembro de 1968, o Jornal do Brasil, um dos mais importantes matutinos da época, foi às bancas com uma edição cuidadosamente planejada para provocar estranheza. Entre as bizarrices, o jornal estampou o aviso "Ontem foi o Dia dos Cegos" e a previsão meteorológica na primeira página. Não satisfeito, anunciou: “Tempo negro. Temperatura sufocante. O ar está irrespirável. O país está sendo varrido por fortes ventos". O dia era de sol forte e o céu escandalosamente azul, mas a edição falava sério: tentava alertar o leitor da presença de censores na redação - naquela madrugada, entrara em funcionamento uma operação militar destinada a censurar toda a imprensa nacional (Schwarcz e Starling, 2018, p. 455)

Um dia antes da ocupação dos censores no jornal, o Ato Institucional $n^{\circ} 5$ tinha sido apresentado 
oficialmente pelos veículos de comunicação. Esta medida do Estado endurecia a repressão e o controle sociais, na medida em que:

[...] suspendia a concessão de habeas corpus e as franquias constitucionais de liberdade de expressão e reunião, permitia demissões sumárias, cassações de mandatos e de direitos de cidadania, e determinava que o julgamento de crimes políticos fosse realizado por tribunais militares, sem direito a recurso (Schwarcz e Starling, 2018, p. 455).

As autoras destacam que junto aos artigos do AI-5 constava o Ato Complementar $n^{\circ} 38$ que estabelecia o fechamento do Congresso Nacional indeterminadamente. Na medida em que o Congresso Nacional operacionalizava o Poder Legislativo federal e modulava o Poder Executivo, a instauração da medida era consolidar o totalitarismo da forma mais violadora.

O AI-5 era uma ferramenta de intimidação pelo medo, não tinha prazo de vigência e seria empregado pela ditadura contra a oposição e a discordância. [...] O AI-5 fez parte de um conjunto de instrumentos e normas discricionárias mas dotadas de valor legal, adaptadas ou autoconferidas pelos militares. Eles depreenderam grande esforço para enquadrar seus atos num arcabouço jurídico e construir um tipo de legalidade plantada no arbítrio - uma legalidade de exceção - capaz de impor graves limites à autonomia dos demais poderes da União, punir dissidentes, desmobilizar a sociedade e limitar qualquer forma de participação política (Schwarcz e Starling, 2018, p. 456).

A tentativa pelo Estado de promover a desmobilização política também envolvia estratégias de restrição à liberdade de expressão artística. Desse modo, uma vez que Apesar de você concebe um enunciado concreto tinha sua circulação vinculada aos meios de comunicação, o dialogismo de Chico Buarque se dava responsivamente à lei de censura prévia.

A lei de censura prévia para livros e publicações foi instituída em 1970, e determinava que os editores enviassem originais para Brasília, antes da publicação. [...] a imprensa estava amordaçada e os jornalistas, perseguidos ou encarcerados. Obras eram retiradas das exposições, como ocorreu no IV Salão de Arte do Distrito Federal e no Salão de Ouro Preto, ambos em 1967, ou na
Bienal da Bahia em 1968. Artistas como Caetano Veloso, Gilberto Gil, Nara Leão, Geraldo Vandré, Odair José e Chico Buarque foram obrigados a se exilar (Schwarcz e Starling, 2018, p. 464).

A principal reflexão posta por essa contextualização sócio-histórica diz respeito a instrumentalização das táticas de opressão da Ditadura Militar de 64, por meio da modulação enunciativa. Dentre as diversas medidas que o Estado da época lançou mão para fazer a manutenção da ideologia dominante, a censura das enunciações emergentes na arte e na imprensa figurou como elemento passível de responsividade das próprias enunciações.

Muito embora em 2020 haja uma garantia constitucional de liberdade de expressão, diversas enunciações emergentes na imprensa continuam responsivas à outras violações a direitos e garantidas fundamentais, como será abordado nas seções subsequentes.

\section{CONDIÇÕES DE EMERGÊNCIA DA ENUNCIAÇÃO DE RENATO TERRA}

Para a elucidação no contexto social e histórico de emergência da crônica de Terra (2020) é preciso retomar pontualmente duas enunciações uma, que antecede a crônica, publicada na Revista Veja em agosto de 2019 e outra, que sucede a crônica, publicada pelo portal UOL em maio de 2020.

O ano de 2019 marca as primeiras declarações de Jair Bolsonaro à imprensa empossado oficialmente como chefe do executivo brasileiro. Ao longo de toda sua vida como político, foram constantes as enunciações que expressavam concordância com as violações aos direitos fundamentais promovidas pela Ditadura Militar. O enunciado vinculado pela Veja sob o título Bolsonaro afirma que torturador Brilhante Ustra é um "herói nacional" demonstra uma continuidade dessa tendência discursiva de negação da historiografia brasileira. 
O presidente Jair Bolsonaro afirmou nesta quinta-feira, 08, que o coronel Carlos Alberto Brilhante Ustra - reconhecido pela Justiça como torturador da ditadura militar - é um "herói nacional". A declaração foi dada por Bolsonaro na saída do Palácio da Alvorada, após ser questionado por jornalistas sobre um almoço que terá com a viúva do coronel, Maria Joseíta Silva Brilhante Ustra (VEJA, 2019).

A escolha do léxico é um ponto nevrálgico a ser ressaltado na enunciação de Bolsonaro. A utilização da palavra "herói" vincula uma carga semântica de admiração, de ideal a ser alcançado e essa construção é atrelada à uma figura histórica ligada ao crime de hediondo de tortura. Diante de uma concepção bakhtiniana de ideologia, na qual as relações sociais estão atreladas ao processo de significação, é possível notar que a construção enunciativa está atrelada a ações do presidente na administração pública.

O ano de 2020 é marcado pela pandemia do covid-19 a qual demanda do Chefe de Estado ações frente às políticas públicas para evitar um aumento do número de mortes, é nesse contexto que as enunciações do presidente seguem retomando uma semântica de heroísmo que remete às violações aos direitos fundamentais. Sakamoto (2020), com o texto Covid,

\subsection{9 mortos: Sob Bolsonaro, Presidência vira} serviço não essencial publicado em sua coluna para o portal UOL, evidencia que as enunciações do presidente repercutem suas decisões quanto à administração pública.

O Brasil atingiu, nesta segunda (11), a marca de 11.519 mortos por covid-19, com mais 397 óbitos registrados nas últimas 24 horas [...] seria um luxo se contássemos com um presidente que não fizesse nada para atrapalhar, como trocar de ministro da Saúde em meio à pandemia, incentivar aglomerações em manifestações próditadura, inspirar carreatas da morte em nome do fim do isolamento ou tentar pressionar a Suprema Corte pela reabertura da economia. Sem contar o passeio de jet ski para "celebrar" 10 mil mortos pela doença (SAKAMOTO, 2020).

Essas considerações do colunista, que emergem um mês após a crônica de Terra (2020), elucidam o contexto sócio histórico atrelado ao processo discursivo que se prolonga no tempo e é composto dialogicamente pelas enunciações presidências e as enunciações da imprensa.

\section{RELAÇÕES DIALÓGICAS E O PROCESSO DE SIGNIFICAÇÃO}

Levando em conta o desenvolvimento teórico sobre dialogismo na abordagem bakhtiniana e os recortes dos contextos sócio históricos apresentados, cabe neste momento a análise dos enunciados concretos. Para fins metodológicos a compreensão das relações dialógicas será delimitada por dois aspectos fundamentais: posicionamento do autor em relação ao momento histórico social e a conclusibilidade como elemento articulador da dialogia. Primeiramente, a composição Apesar de você de Holanda (1970).

Hoje você é quem manda

Falou, tá falado

Não tem discussão

A minha gente hoje anda

Falando de lado

E olhando pro chão, viu

Você que inventou esse estado

E inventou de inventar

Toda a escuridão

Você que inventou o pecado

Esqueceu-se de inventar

$\mathrm{O}$ perdão

Apesar de você

Amanhã há de ser

Outro dia

Eu pergunto a você

Onde vai se esconder

Da enorme euforia

Como vai proibir

Quando o galo insistir

Em cantar

Água nova brotando

E a gente se amando

Sem parar

Quando chegar o momento

Esse meu sofrimento

Vou cobrar com juros, juro

Todo esse amor reprimido

Esse grito contido

Este samba no escuro

Você que inventou a tristeza

Ora, tenha a fineza

De desinventar

Você vai pagar e é dobrado

Cada lágrima rolada

Nesse meu penar 
Apesar de você

Amanhã há de ser

Outro dia

Inda pago pra ver

O jardim florescer

Qual você não queria

Você vai se amargar

Vendo o dia raiar

Sem lhe pedir licença

E eu vou morrer de rir

Que esse dia há de vir

Antes do que você pensa

Apesar de você

Amanhã há de ser

Outro dia

Você vai ter que ver

A manhã renascer

E esbanjar poesia

Como vai se explicar

Vendo o céu clarear

De repente, impunemente

Como vai abafar

Nosso coro a cantar

Na sua frente

Apesar de você

Amanhã há de ser

Outro dia

Você vai se dar mal

Etc. e tal

(HOLANDA, 1978, p.B16)

Analisar essa composição musical sob a ótica de enunciado concreto demanda observar que a dialogia é um processo comunicativo estruturado pela atribuição de sentido aos signos linguísticos em meio a um contexto ideológico e social de produção e recepção.

O ponto de partida semântico da composição de Holanda (1970) é a ambiguidade. Na medida em que que as condições enunciativas de produção do compositor referem-se à censura imposta pelo AI-5, era demandado um trabalho com a língua que possibilitasse mascarar o posicionamento do autor. Acentuar a multiplicidade de significação léxica era a ferramenta para que as composições, que expressassem um posicionamento crítico ao regime militar, pudessem circular e serem recepcionadas pelos interlocutores.
A interpretação da canção pelos censuradores na época atribuiu ao pronome "você" a figura de uma mulher autoritária e deste modo o processo de significação do enunciado foi direcionado como uma narrativa de um relacionamento amoroso. Contudo, a atribuição do pronome "você" ao então presidente do Brasil Emílio Garrastazu Médici. Outro ponto central é a utilização do substantivo "estado", que na enunciação figura com letra minúscula referindo-se tanto à situação de um relacionamento amorosa, mas pode ser concebido como Estado soberano autoritário.

Desse modo é possível notar posicionamento do autor em relação ao momento histórico social é de crítica à opressão promovida pelo Regime Militar de 64, à truculência e horror criados pelo Estado de Médici, articulando uma esperança de melhora, que viria posteriormente com a redemocratização. Essa enunciação é retomada de forma explícita numa entrevista concedida à revista Rolling Stone.

Posso atribuir essa datação às músicas mais agudas do tempo da ditadura. Algumas músicas que foram criadas meio que como uma função extramusical. Ou seja, com a intenção de desafiar o regime, a censura etc. Vamos dizer: músicas sinceras. Essas vivem menos, talvez seja isso. Outras ficam datadas musicalmente, porque são canções, harmonias que não representam mais o que me interessa hoje como uma solução harmônica, construção melódica. Essas têm remédio porque eu posso refazer, rearranjar, reharmonizar. Agora, a meia dúzia de canções "Apesar de Você", "Cálice", "Deus lhe Pague" essas, para mim, ficaram datadas. Elas correspondem ao momento político e não fazem grande sentido hoje [...]

Pode ser, pode ser. Porque as pessoas têm uma lembrança afetiva da música. Elas gostam de determinadas músicas porque elas remetem a uma época feliz da sua vida. "Essa é a música que ouvi quando conheci a minha namorada." Isso existe independentemente do que diz a letra. Quando eu digo que não tenho vontade de cantálas porque elas são datadas, isso é pra mim! Eu não tenho vontade de cantar. Acredito que as pessoas que não tinham posições políticas claras na época possam ouvir "Apesar de Você" hoje e encontrar um valor afetivo muito grande, independentemente do que a letra diz. Isso até contraria um pouquinho o que você falou, porque as pessoas se deixam levar pela música e, às vezes, cantam a letra sem prestar atenção no que estão dizendo. Isso existe, basta lembrar as 
músicas que você cantava na infância. "Que engraçado, essa música quer dizer isso!" Você não entendia o que era e repetia. $\mathrm{Ou}$ as pessoas que cantam em inglês e muitas vezes não sabem o que diz aquilo. Elas gostam do som e aprendem a dizer aquelas palavras, não têm muita noção do que elas dizem. Ouvem músicas que fazem um enorme sucesso no mundo inteiro e que, na verdade, são compreendidas por uma parcela bem menor de pessoas (TERRON, 2011).

Os termos "datação" e "datada" nessa enunciação atribuem à contextualização social e histórica um caráter estanque, de permanência e desatualização. Considerando a possibilidade específica de significação da canção Apesar de você como crítica ao regime político é possível afirmar que foi gerada no compositor uma atitude discursiva responsiva. É justamente essa resposta discursiva, sob uma perspectiva bakhtiniana, que atribui dinâmica ao termo "datação".

Localizar essa enunciação no seu contexto social e histórico, sob viés da Análise Dialógica do Discurso, é definir um ponto de partida para significações posteriores. Assim, a possibilidade de conclusibilidade na enunciação é estruturada para além do fim literal da composição musical, a possibilidade dessa composição ser retomada e resignificada em 2020é o elemento articulador da dialogia. Essa retomada é realizada pela enunciação Acabou pra você de Terra (2020) transcrita a seguir.

\section{Capitão}

Virou uma rainha

Hoje você já não manda

Falou tudo errado

Só traz confusão

A minha terra é redonda

A besta é quadrada

Não tem condição, viu?

Você que inventou esse estrago

E inventou de inventar

A desinformação

Você que inventou Golden shower

Esqueceu de governar

A nação

Acabou pra você

\author{
Amanhã há de ser \\ Outro dia \\ Eu pergunto a você \\ Onde vai esconder \\ Seu exame do vírus \\ Como vai proibir \\ Quando o Braga insistir \\ Em mandar? \\ Panelaço cantando \\ E a caneta falhando \\ Sem parar \\ Quando o Queiroz for detento \\ E no depoimento \\ Ele contar tudo, tudo \\ No celular do bandido \\ Estiver contido \\ Um esquema obscuro \\ Você que inventou a torpeza \\ Não vai ter a fineza \\ De se ausentar \\ Você vai dizer que é fraudada \\ Cada urna inspecionada \\ Mas não vai provar \\ Acabou pra você \\ Acabou pra você \\ Amanhã há de ser \\ Outro dia \\ (TERRA, 2020, p.B16)
}

A construção de sentido da enunciação de Terra (2020), diferentemente da composição de Holanda (1970), parte da referência direta às enunciações feitas pelo atual chefe do Executivo, bem como de seus apoiadores, que circulam na imprensa e nas redes sociais. Além disso, sob o âmbito do gênero discursivo, uma das intenções comunicativas da crônica é retomar enunciações que circulam na imprensa noticiando acontecimentos de interesse público, nesse caso acontecimentos que envolvem o Governo Federal.

As condições enunciativas de produção do jornalista são ambientadas na liberdade de imprensa e forte presença da comunicação por meio das plataformas digitais. Desse modo, mascarar o tom crítico ao governo não é uma condição de circulação 
da enunciação, uma vez que não há mais uma institucionalização da censura. Assim, o pronome "você" refere-se diretamente ao atual presidente Jair Bolsonaro sem estruturação semântica ambígua, mas articulando termos explícitos com ocorrência tanto nas enunciações da imprensa sobre o governo, quanto nas declarações do próprio presidente.

O posicionamento do autor é de crítica ao atual governo e é nesse sentido que as relações dialógicas são articuladas. Muito embora haja uma dialogia estrutural dos textos com a intersecção de uma organização em versos e estrofes e um desenrolar narrativo a partir do termo como "você", as relações dialógicas entre as duas enunciações se desenvolvem por meio da ideologia.

Uma vez que a Análise Dialógica do Discurso desenvolve a ideia de ideologia como uma estruturação valores oriundos da contraposição entre a ideologia do cotidiano e ideologia dominante, num contexto processual de significação de signos, há um ele dialógico entre Apesar de você e Acabou pra você. A enunciação de Holanda (1970), no contexto social e histórico de 1964, é expressão da ideologia do cotidiano que preconizava a valorização da liberdade civil frente à ideologia dominante que era estruturada na opressão civil politicamente institucionalizada. Desta feita, a enunciação tem seu significado vinculado à luta pela conquista dos direitos de primeira dimensão.

A enunciação de Terra (2020) é uma manifestação discursiva da ideologia do cotidiano contemporâneo atrelada à valorização dos direitos sociais que devem ser garantidos pelo Estado de forma ativa, em contraposição à ideologia dominante pautada na valorização dos interesses pessoais em detrimento aos sociais. Assim, a enunciação tem seu significado dilatado, pois está vinculado à luta pela conquista dos direitos de segunda, terceira e quarta dimensão.
Ambos os enunciados configuram elos diante de uma cadeia discursiva, a enunciação de 2020 é responsiva tanto às enunciações contemporâneas sobre a situação política contemporânea, como também à enunciação de 1970. Nesse sentido é possível notar como o discurso flui ao longo do tempo e espaço, as enunciações são indissociáveis e sua completa compreensão demanda o entendimento de discurso como um processo contínuo.

\section{CONCLUSÃO}

Conforme foi visto, a perspectiva bakhtiniana de dialogia é fundante da linguagem e por isso é extensível aos processos de enunciação de modo geral. A identificação da dialogia entre enunciados concretos específicos como ocorreu do presente trabalho teve duas intenções.

De um lado foi possível apurar a concepção dos conceitos bakhtinianos, delimitando-os por meio de uma exemplificação; de outro refinar a compreensão dos enunciados concretos por meio da materialização de Análise Dialógica do Discurso que possibilita a compreensão deles como elos de uma cadeia discursiva.

Diante da amplitude da Análise Dialógica do Discurso foi necessária uma breve restrição das análises enunciativas aos aspectos de conclusibilidade e responsividade. Por conseguinte, vê-se que a conclusibilidade de Apesar de você abriu possibilidade para a construção responsiva de Acabou pra você. Explicitar essa relação é fundamental para compreender a linguagem constituída pelo discurso dialógico e vinculada ao momento social e histórico.

Todos os autores declararam não haver qualquer potencial conflito de interesses referente a este artigo.

\section{REFERÊNCIAS}

BAKHTIN, Mikhail. Estética da criação verbal. $6^{a}$ ed. São Paulo: Editora WMF Martins Fontes, 2011. 
BAKHTIN, Mikhail. Discurso no Romance. In: Questões de Literatura e Estética: A Teoria do Romance. $5^{a}$ ed. São Paulo: Editora Hucitec, 2002. p. 71-164.

BRAIT, Beth e MELO, Rosineide de. Enunciado/enunciado concreto/enunciação. In: BRAIT, Beth. Bakhtin: conceitos-chave. $2^{\mathrm{a}}$ ed. São Paulo: Contexto, 2018, p.61-78.

FIORIN, José Luiz. Interdiscursividade e intertextualidade. In: BRAIT, Beth. Bakhtin: outros conceitos-chave. $1^{a}$ ed. São Paulo: Contexto, 2018. p. 161-193.

GODOY, Arilda Schmidt. Pesquisa qualitativa: tipos fundamentais. RAE-Revista de Administração de Empresas, [S.1.], v. 35, n. 3, p. 20-29, mai. 1995. ISSN 2178-938X. Disponível em: http://bibliotecadigital.fgv.br/ojs/index.php/rae/article /view/38200. Acesso em: 18 Jul. 2020.

HOLANDA, Chico Buarque de. Apesar de você. Chico Buarque, $1970 . \quad$ Disponível em:http://www.chicobuarque.com.br/construcao/mest re.asp?pg=apesarde_70.htm. Acesso em 15 jun. 2020.

MIOTELLO, Valdemir. Ideologia. In: BRAIT, Beth. Bakhtin: conceitos-chave. $2^{\mathrm{a}}$ ed. São Paulo: Contexto, 2018, p.167-176.

SAKAMOTO, Leonardo. Covid, 11.519 mortos: Sob Bolsonaro, Presidência vira serviço não essencial.
Notícias UOL, 2020. Disponível em: https://noticias.uol.com.br/colunas/leonardosakamoto/2020/05/11/covid-11519-mortos-sobbolsonaro-presidencia-vira-servico-naoessencial.htm. Acesso em 07 jun. 2020.

SCHWARCZ, Lilia Moritz e STARLING, Heloisa Murgel. Brasil: Uma Biografia. $2^{\mathrm{a}}$ ed. São Paulo: Companhia das Letras, 2018.

TERRA, Renato. Acabou pra você. São Paulo: Folha de São Paulo, 2020. Disponível em:https://renatoterra.blogfolha.uol.com.br/2020/04/1 0/acabou-pra-voce/. Acesso em 07 jun. 2020.

TERRON, Paulo. Entrevista RS: Chico Buarque. São Paulo: Rolling Stone, 2011. Disponível em:https://rollingstone.uol.com.br/edicao/edicao-

61/entrevista-rs-chico-buarque/. Acesso em 15 jun. 2020 .

VEJA. Bolsonaro afirma que torturador Brilhante Ustra é um "herói nacional". Grupo Abril, 2019. Disponível em:https://veja.abril.com.br/politica/bolsonaroafirma-que-torturador-brilhante-ustra-e-um-heroinacional/. Acesso em 07 jun. 2020.

VOLÓCHINOV, Valentin. Marxismo e filosofia da linguagem. Problemas fundamentais do método sociológico na ciência da linguagem. $2^{\mathrm{a}}$ ed. São Paulo: Editora 34, 2018. 